\title{
EFFECT OF FEEDING DIFFERENT LEVELS OF PROTEIN AND ENERGY OF BUREAU OF INDIAN STANDARD SPECIFICATION ON PRODUCTION PERFORMANCE OF CROSSBRED (HS X GH) GROWER PIG
}

\author{
K. BARMAN ${ }^{1 *}$, S. BANIK ${ }^{1}$, R. THOMAS ${ }^{1}$, D. KONWAR ${ }^{2}$, \\ B. C. DAS ${ }^{1}$, S. BORA ${ }^{1}$ AND S. RAJKHOWA ${ }^{1}$
}

${ }^{1}$ ICAR-National Research Centre on Pig, ICAR, Rani-781 131, Guwahati, Assam, India ${ }^{2}$ Faculty of Veterinary Science and Animal Husbandry, SKUAST-Jammu, RS Pura, Jammu-181 102, Jammu \& Kashmir, India

\begin{abstract}
Present research work was conducted to study the effect of different levels of protein and energy on growth and nutrient utilization in crossbred grower pigs. Twenty four crossbred grower pigs were divided into four groups of six each. Animals were fed four different rations containing $100 \%$ of protein and energy of Bureau of Indian Standard (BIS), $100 \%$ of protein and $75 \%$ of energy of BIS, $75 \%$ of protein and $100 \%$ of energy of BIS, and $75 \%$ of protein and $75 \%$ of energy of BIS in $T_{1}, T_{2}, T_{3}$ and $T_{4}$ groups, respectively to observe its effect on growth and nutrient utilization in crossbred grower pig. The pigs were fed on the experimental grower rations twice daily. Crude protein $(\mathrm{CP})$ content $(\%)$ of the ration was ranged from $14.10 \pm 0.32$ to $18.71 \pm 0.54$. The average dry matter $(D M)$ intake (g/day) was similar across all the groups which were ranged from $1357.0 \pm 5.4$ to 1362.5 . The majority of the nutrient digestibility coefficients were found higher $(P<0.01)$ in $T_{3}$ group followed by $T_{2}, T_{1}$ and $T_{4}$ groups. The average body weight gain (g/day) was 395.7 $\pm 33.1,383.8 \pm 21.1$, 379.9 \pm 12.6 and $375.3 \pm 46.0$ in $T_{1}, T_{2}, T_{3}$ and $T_{4}$ groups, respectively. The cost of production per kg live weight (Rs.) was ranged from $55.30 \pm 1.7$ in $T_{3}$ to $64.90 \pm 8.80$ in $T_{4}$ group and the values of others were within this range. The cost of production per $\mathrm{kg}$ live weight was lowest $(\mathbf{P}<\mathbf{0 . 0 5})$ in $\mathrm{T}_{3}$ in comparison to other groups. It is concluded that ration containing $75 \%$ of protein and $100 \%$ of energy specified by BIS, can meet the nutritional requirement of grower pig without affecting the growth, feed conversion ratio (FCR) and economy of feeding.
\end{abstract}

Key words: BIS, Energy, Grower pig, Production performance, Protein

\section{INTRODUCTION}

Feed costs represent $70-75 \%$ of the operating cost in swine production. Among feed cost protein alone represent about $40-50 \%$ of total feed cost. This is particularly evident in starter diet which is high in protein sources like soya bean, fish meal, groundnut cake etc. and energy sources (Maxwell and Carter, 2001). It was reported that energy intake in pigs depends on many animal and environmental factors like body weight, genotype, sex, health, climate, housing system, pig density, feed characteristics etc. (Li and Patience, 2016; Pierozan et al., 2016). In pig, feed intake is related to energy concentration of the diet and high energy level in the diet decrease feed intake where as low energy intake decreases protein deposition (Lewis and Southern, 2001; Noblet and Van Milgen, 2013). It was reported

\footnotetext{
"Corresponding Author
} 
that the pig feed containing low protein improved faecal consistency score, enteric health and growth performance (Opapeju et al., 2015; Wu et al., 2015; Wen et al., 2018). Therefore, present study was conducted to observe the effect of different levels of protein and energy which were either equal to or below the requirement of Bureau of Indian Standard (BIS, 1986) on growth and nutrient utilization in crossbred grower pig.

\section{MATERIALS AND METHODS}

Twenty four crossbred (Hampshire $\mathrm{x}$ Ghungroo, HSxGH) grower pigs $(22.70 \pm 0.35$ to $23.00 \pm 2.46 \mathrm{~kg}$ bwt) were divided into four groups of six in each in a randomized block design. The trial was conducted for a period of 60 days. Animals were fed on four different rations containing $100 \%$ of protein and energy of BIS, $100 \%$ of protein and $75 \%$ of energy of BIS, $75 \%$ of protein and $100 \%$ of energy of BIS, and $75 \%$ of protein and $75 \%$ of energy of BIS in $\mathrm{T}_{1}, \mathrm{~T}_{2}, \mathrm{~T}_{3}$ and $\mathrm{T}_{4}$ groups respectively. The pigs were fed on the experimental rations twice daily. Digestibility trial was conducted on the middle of experiment. The calculated energy content of the rations was 3150, 2439, 3161 and $2454 \mathrm{kcal} \mathrm{ME} / \mathrm{kg}$ diet in $\mathrm{T}_{1}, \mathrm{~T}_{2}, \mathrm{~T}_{3}$ and $\mathrm{T}_{4}$ groups, respectively. The lysine and methionine are balanced in all the rations as per requirement. Proximate composition was done as per AOAC (1990). Data were analyzed as per method of Snedecor and Cochran (1989).

\section{RESULTS}

The protein content of the ration ranged from $13.65 \pm 0.52\left(75 \%\right.$ of BIS) in $\mathrm{T}_{3}$ to $18.71 \pm 0.54$ (100\% of BIS) in $\mathrm{T}_{1}$. Nitrogen free extract content $(\% \mathrm{DM})$ of the rations ranged from $67.30 \pm 0.54$ in $\mathrm{T}_{1}$ to $73.98 \pm 0.34$ in $\mathrm{T}_{4}$ (Table 1). The digestibility of dry matter (DM), organic matter $(\mathrm{OM})$, crude protein $(\mathrm{CP})$, ether extract (EE), crude fiber (CF) and nitrogen free extract (NFE) were ranged from $82.94 \pm 0.21$ to $86.36 \pm 0.17 ; 84.63 \pm 0.18$ to $87.72 \pm 0.16$; $83.57 \pm 0.19$ to $89.03 \pm 0.33 ; 58.30 \pm 1.12$ to $74.57 \pm 3.97 ; 61.98 \pm 0.43$ to $63.31 \pm 0.47$ and $85.66 \pm 0.17$ to $90.08 \pm 0.22$ respectively. In most of the treatments, digestibility of nutrients showed increasing trend $(\mathrm{P}<0.05)$ from $\mathrm{T}_{1}$ to $\mathrm{T}_{3}$ and thereby reduced in $\mathrm{T}_{4}$ (Table 2 ).

The feed intake (g/day) was ranged from $1357.4 \pm 6.5$ to $1362.5 \pm 7.5$ in $\mathrm{T}_{1}$ and $\mathrm{T}_{2}$ respectively and others namely $T_{3}$ and $T_{4}$ were within this range of variation (Table 3). The DM intake was found similar $(\mathrm{P}>0.05)$ across all treatment groups. Average growth rate (g/day) was ranged from $375.3 \pm 46.0$ in $\mathrm{T}_{4}$ group $(75 \%$ of energy and protein of BIS) to $395.7 \pm 33.1$ in $\mathrm{T}_{1}$ group respectively (Table 3 ). The feed conversion ratio (FCR) and feed cost $(\mathrm{Rs} . / \mathrm{kg}$ gain) ranged from $3.50 \pm 0.29$ to $3.58 \pm 0.19$ and $55.3 \pm 1.7$ to $65.1 \pm 3.5$, respectively (Table 3 ).

Table 1. Proximate composition of grower ration containing different level of protein and energy

\begin{tabular}{ccccccc}
\hline Grower feed & OM\% & CP\% & CF\% & EE\% & Ash\% & NFE\% \\
\hline $\mathrm{T}_{1}$ & $95.79 \pm 1.01$ & $18.71 \pm 0.54$ & $5.73 \pm 0.37$ & $4.05 \pm 0.64$ & $4.22 \pm 1.01$ & $67.30 \pm 0.54$ \\
$\mathrm{~T}_{2}$ & $94.92 \pm 0.37$ & $17.64 \pm 0.08$ & $5.31 \pm 0.18$ & $2.76 \pm 0.34$ & $5.09 \pm 0.37$ & $69.21 \pm 0.96$ \\
$\mathrm{~T}_{3}$ & $94.70 \pm 0.11$ & $13.65 \pm 0.52$ & $5.62 \pm 0.16$ & $2.05 \pm 0.59$ & $5.28 \pm 0.13$ & $73.41 \pm 0.83$ \\
$\mathrm{~T}_{4}$ & $94.89 \pm 0.10$ & $14.10 \pm 0.32$ & $4.71 \pm 0.15$ & $2.10 \pm 0.22$ & $5.12 \pm 0.10$ & $73.98 \pm 0.34$ \\
\hline
\end{tabular}

$\mathrm{T}_{1}: 100 \%$ of protein and energy of BIS (Bureau of Indian Standard), $\mathrm{T}_{2}: 100 \%$ of protein and $75 \%$ of energy of BIS, $\mathrm{T}_{3}: 75 \%$ of protein and $100 \%$ of energy of BIS, and $\mathrm{T}_{4}: 75 \%$ of protein and $75 \%$ of energy of BIS 
Table 2. Effect of different levels of protein and energy on digestibility of nutrients in crossbred grower pigs

\begin{tabular}{cllllll}
\hline Group & \multicolumn{1}{c}{ DM } & \multicolumn{1}{c}{ OM } & \multicolumn{1}{c}{ CP } & EE & CF & NFE \\
\hline $\mathrm{T}_{1}$ & $82.94^{\mathrm{a}} \pm 0.21$ & $84.63^{\mathrm{a}} \pm 0.18$ & $87.01^{\mathrm{b}} \pm 0.16$ & $72.39^{\mathrm{c}} \pm 0.91$ & $62.12 \pm 0.91$ & $85.66^{\mathrm{a}} \pm 0.17$ \\
$\mathrm{~T}_{2}$ & $85.31^{\mathrm{b}} \pm 0.44$ & $86.76^{\mathrm{b}} \pm 0.52$ & $89.03^{\mathrm{c}} \pm 0.33$ & $74.57^{\mathrm{c}} \pm 3.97$ & $62.44 \pm 0.05$ & $88.82^{\mathrm{b}} \pm 0.34$ \\
$\mathrm{~T}_{3}$ & $86.36^{\mathrm{c}} \pm 0.17$ & $87.72^{\mathrm{c}} \pm 0.16$ & $86.93^{\mathrm{b}} \pm 0.17$ & $64.36^{\mathrm{b}} \pm 0.38$ & $63.31 \pm 0.47$ & $90.08^{\mathrm{c}} \pm 0.22$ \\
$\mathrm{~T}_{4}$ & $84.71^{\mathrm{bd} \pm 0.17}$ & $86.76^{\mathrm{bd}} \pm 0.22$ & $83.57^{\mathrm{a}} \pm 0.19$ & $58.30^{\mathrm{a}} \pm 1.12$ & $61.98 \pm 0.43$ & $89.36^{\mathrm{b}} \pm 0.20$ \\
P Value & $0.01^{* *}$ & $0.04^{*}$ & $0.01^{* *}$ & $0.05^{*}$ & 0.626 & $0.01^{* *}$
\end{tabular}

a,b,c,d different superscript in a column differ significantly, $\left({ }^{* *}, \mathrm{P}<0.01, *, \mathrm{P}<0.05\right) ; \mathrm{T}_{1}: 100 \%$ of protein and energy of BIS, $\mathrm{T}_{2}: 100 \%$ of protein and $75 \%$ of energy of BIS, $\mathrm{T}_{3}: 75 \%$ of protein and $100 \%$ of energy of BIS, and $\mathrm{T}_{4}: 75 \%$ of protein and $75 \%$ of energy of BIS

Table 3. Effect of different level of protein and energy on feed intake, growth, FCR and cost of feeding of crossbred (HSxGH) grower pig

\begin{tabular}{llllll}
\hline \multicolumn{1}{c}{ Parameters } & \multicolumn{1}{c}{$\mathbf{T}_{\mathbf{1}}$} & \multicolumn{1}{c}{$\mathbf{T}_{\mathbf{2}}$} & \multicolumn{1}{c}{$\mathbf{T}_{\mathbf{3}}$} & \multicolumn{1}{c}{$\mathbf{T}_{\mathbf{4}}$} & $\mathbf{P}$ value \\
\hline Feed intake, g/day & $1357.4 \pm 6.5$ & $1362.5 \pm 7.5$ & $1357.0 \pm 5.4$ & $1361.0 \pm 4.5$ & 0.894 \\
Initial body weight, $\mathrm{kg}$ & $22.90 \pm 2.83$ & $23.00 \pm 2.46$ & $22.90 \pm 2.21$ & $22.70 \pm 0.35$ & 0.999 \\
Final body weight, $\mathrm{kg}$ & $48.45 \pm 2.89$ & $47.28 \pm 2.57$ & $48.63 \pm 2.06$ & $46.63 \pm 2.90$ & 0.968 \\
Growth, g/day & $395.7 \pm 33.1$ & $383.8 \pm 21.1$ & $387.0 \pm 13.0$ & $375.3 \pm 46.0$ & 0.888 \\
FCR (Feed conversion ratio) & $3.50 \pm 0.29$ & $3.58 \pm 0.19$ & $3.52 \pm 0.11$ & $3.81 \pm 0.52$ & 0.907 \\
Feed cost/kg gain & $62.0 \pm 5.1$ & $65.1 \pm 3.5$ & $55.3 \pm 1.7$ & $64.9 \pm 8.8$ & 0.566 \\
\hline
\end{tabular}

$\mathrm{T}_{1}: 100 \%$ of protein and energy of BIS (Bureau of Indian Standard), $\mathrm{T}_{2}: 100 \%$ of protein and $75 \%$ of energy of BIS, $\mathrm{T}_{3}: 75 \%$ of protein and $100 \%$ of energy of BIS, and $\mathrm{T}_{4}: 75 \%$ of protein and $75 \%$ of energy of BIS;

\section{DISCUSSION}

From the proximate composition of the present study it was found that $\mathrm{CP} \%$ of experimental diet was reduced by $3.99 \%$ to $4.61 \%$ in $\mathrm{T}_{3}$ and $\mathrm{T}_{4}$ groups when diet was formulated to meet the $75 \%$ protein requirement of BIS (Table 1).

The digestibility coefficient of dry matter, organic matter, crude protein and nitrogen free extract was found higher $(\mathrm{P}<0.05)$ in $\mathrm{T}_{3}$ group in comparison to other three groups, while digestibility of ether extract was similar in $\mathrm{T}_{1}$ and $\mathrm{T}_{2}$ groups and reduced significantly $(\mathrm{P}<0.05)$ in $\mathrm{T}_{3}$ and $\mathrm{T}_{4}$ groups (Table 2). The crude fiber digestibility was found similar across the treatment groups. In a similar study, Ball et al. (2013) reported that energy digestibility decreased with decreasing level of CP in diets containing $6.9 \mathrm{~g} / \mathrm{kg}$ available lysine in finisher crossbred pigs (Landrace $x$ Large White Yorkshire). Similar to present findings, Kashyap (2010) also found higher digestibility of dry matter in high protein high energy diet in indigenous Ghungroo pig. The increase digestibility of crude protein in group $T_{1}$ and $\mathrm{T}_{2}$ might be due to high level of protein in those diets. Similar high digestibility of protein was also reported by Kashyap (2010). Crude fiber digestibility was found similar across the 
groups. Similar result also reported by other workers (Myer et al., 1975; Kashyap, 2010). In a similar study, Fang et al. (2019) also reported that feeding of low protein and high energy diet in crossbred (Duroc x Large White Yorkshire $\mathrm{x}$ Landrace) weaner pigs improved the nutrient digestibility. In another study, Zhao et al. (2019) reported that $3.5 \%$ decreased in dietary protein than requirement did not affect the nutrient digestibility while significantly $(\mathrm{P}<0.05)$ reduces faecal nitrogen excretion and Escherichia coli count.

In the present study, although growth was found slightly higher at $100 \%$ energy and protein of BIS, but, there was no significant difference on growth among the treatment groups. Similar to present finding, several workers (Sharda et al., 1976; Kennelly and Aherne, 1980; Phuah and Hutagalung, 1982) reported that growth rate was decreased with decreased level of energy in the diet of pig. In a similar study, Fang et al. (2019) reported that feeding of low protein and high energy diet in crossbred (Duroc x Large White Yorkshire $\mathrm{x}$ Landrace) weaner pigs improved the growth

\section{REFERENCES}

AOAC, 1990. Official Methods of Analysis, $15^{\text {th }}$ Edn. (Eds. Kenneth Helrich), Association of Official Analytical Chemists, Inc., Suite 400, 2200 Wilson Boulevard, Arlington, Virginia 22201, USA

Ball MEE, Magowan E, McCracken KJ , Beattie VE, Bradford R et al., 2013. The effect of level of crude protein and available lysine on finishing pig performance, nitrogen balance and nutrient digestibility. Asian-Australas J Anim Sci, 26(4): 564-572, doi: 10.5713/ ajas.2012.12177

Barman K, Das A and Bora S, 2013. Effect of feeding different levels of protein and energy on performance of cross bred (Hampshire $\mathrm{x}$ Ghungroo) starter pig. Indian Vet J, 90(4): 36-37 performance. In another study, Zhao et al. (2019) reported that $3.5 \%$ decreased in dietary protein than requirement did not affect the growth performance of growing-finishing pigs. In contrast to this, other researchers (Ribeiro et al., 2016; Lee et al., 2017) found that energy level did not affect growth performances in weaning piglets.

The feed conversion ratio was found slightly higher in $\mathrm{T}_{2}, \mathrm{~T}_{3}$ and $\mathrm{T}_{4}$ groups, but there were no significant difference between the groups. Similar, result also reported by Barman et al. (2013) when experimental starter crossbred pigs were fed with different level of protein and energy of BIS. Feed cost per kg gain (Rs.) was found similar across the treatment groups. Similar finding was also reported by Barman et al. (2013) in starter crossbred pigs by feeding different level of protein and energy of BIS.

From this study, it can be concluded that $75 \%$ protein and $100 \%$ energy of Bureau of Indian Standard can meet the nutritional requirement of grower pig without affecting the production performances.

BIS, 1986. BIS Specifications for Compounded Feeds for Pigs (IS: 7472 - 1986), Bureau of Indian Standard, 1986, India

Fang LH, Jin YH, Do SH, Hong JS, Kim BO et al., 2019. Effects of dietary energy and crude protein levels on growth performance, blood profiles, and nutrient digestibility in weaning pigs. Asian-Australas J Anim Sci, 32(4): 556563, doi:10.5713/ajas.18.0294

Kashyap B, 2010. Effect of different dietary levels of energy and protein on growth and nutrient utilization in indigenous pig (Ghungroo), M.V.Sc. Thesis, Submitted to Assam Agricultural University, Jorhat, Assam

Kennelly JJ and Aherne FX, 1980. The effect of fiber 
addition to diets formulated to contain different level of energy and protein on growth and carcass quality of swine. Can J Anim Sci, 60(2): 385-393

Lee JH, Kim HB, Yun W, Kwak WG, Lee CH et al., 2017. Effects of reducing dietary crude protein and metabolic energy in weaned piglets. S Afr J Anim Sci, 47(4): 574-581, doi: 10.4314/ sajas.v47i4.16

Lewis AJ and Southern LL, 2001. Swine nutrition, $2^{\text {nd }}$ Edn., Boca Raton London New York Washington DC: CRC Press; 2001

Li Q and Patience J, 2016. Factors involved in the regulation of feed and energy intake of pigs. Anim Feed Sci Technol, 233: 22-33, doi: 10.1016/j anifeedsci. 2016.01.001

Maxwell CV and Carter SD, 2001. Feeding the weaned pig: In Swine Nutrition, $2^{\text {nd }}$ Edn., A. J. Lewis and L. L. Southern, ed. CRC Press, Boca Raton, FL, pp691-715

Myer RO, Cheeke PR and Kennick WH, 1975. Utilization of alfalfa protein concentrate by swine. J Anim Sci, 40(5): 885-891, doi: 10.2527/jas1975.405885x

Noblet J and Milgen JV, 2013. Energy and energy metabolism in swine. In: Chiba LI, editor. Sustainable swine nutrition. Ames, IA, USA: John Wiley \& Sons; 2013. pp23-57

Opapeju FO, Roriguez-Lecompte JC, Rademacher M, Krause DO and Nyachoti CM, 2015. Low crude protein diets modulate intestinal responses in weaned pigs challenged with Escherichia coli K88. Can J Anim Sci, 95(1): 71-78, doi: 10.4141/cjas-2014-071

Pierozan CR, Agostini P, Gasa J, Novais AK, Dias CP et al., 2016. Factors affecting the daily feed intake and feed conversion ratio of pigs in grow-finishing units: the case of a company. Porc Health Manag 2(7), doi: 10.1186/s40813-016-0023-4

Phuah CH and Hutagalung RI, 1982. Effect of varying dietary energy and protein levels on performance, nutrient digestibility and carcass characteristic of pigs. Nutr Abstr Rev, 52: 105

Ribeiro AML, Farina G, Vieira MS, Perales VA and Kessler AM, 2016. Energy utilization of light and heavy weaned piglets subjected to different dietary energy levels. $\mathrm{R}$ Bras Zootec, 45 (9): 532-539, doi: 10.1590/s180692902016000900005

Sharda DP, Yadav KR and Pradhan K, 1976. Effect of energy restriction in the diet on the performance and carcass quality of market pigs. Indian $\mathbf{J}$ Anim Sci, 47: 743-745

Snedecor GW and Cochran WG, 1989. Statistical Methods, $8^{\text {th }}$ Edn., Iowa University press, Ames, Iowa (USA)

Wen X, Wang L, Zheng C, Yang X, Ma X et al., 2018. Fecal scores and microbial metabolites in weaned piglets fed different protein sources and levels. Anim Nutr, 4(1): 31-36, doi: 10.1016/j.aninu.2017.10.006

Wu YP, Jiang ZY, Zheng C, Wang L, Zhu C et al., 2015. Effects of protein sources and levels in antibiotic-free diets on diarrhea, intestinal morphology, and expression of tight junctions in weaned piglets. Anim Nutr, 1(3): 170-176, doi: 10.1016/ j.aninu.2015.08.013

Zhao Y, Tian G, Chen D, Zheng P, Yu J et al., 2019. Effects of varying levels of dietary protein and net energy on growth performance, nitrogen balance and faecal characteristics of growing-finishing pigs. $\mathrm{R}$ Bras Zootec, 48(1), doi:10.1590/rbz 4820180021 